\title{
FISCAL BEHAVIOUR OF SUBNATIONAL GOVERNMENTS IN NIGERIA: AN AUGMENTED AUTOREGRESSIVE DISTRIBUTED LAG (ARDL) APPROACH
}

\author{
Monica Adele Orisadare ${ }^{D}$, Kazeem Fasoye $($ D \\ ${ }^{1}$ Department of Economics, Obafemi Awolowo University, Ile-Ife, Nigeria \\ ${ }^{2}$ Department of Economics, Obafemi Awolowo University, Nigeria
}

\section{ARTICLE INFO}

Recieved: 26 November 2021

Revised: 19 February 2022

Accepted: 20 Februaty 2022

Keywords: ARDL Bounds Test, Cointegration, Lagged Level Variables, Expenditure, Debt

Corresponding Author: Kazeem Fasoye

Email: qosimfasoye@yahoo.com Copyright $\odot 2021$ by author(s)

This work is licensed under the Creative Commons Attribution International License (CC BY 4.0). $\mathrm{http} / / /$ creativecommons.org/licenses/ by/4.0/
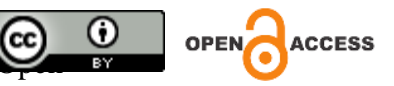

\begin{abstract}
Purpose: The paper examined the determinants of fiscal behavior of subnational governments in Nigeria between 1981 and 2020.

Approach/Methodology/Design: An Augmented Autoregressive Distributed Lag (ARDL) bounds test for cointegration which involves an extra F-test on the lagged level variables in the ARDL equation was employed.

Findings: The results reveal that finances of the lower level of governments in Nigeria have not been managed optimally as there appeared a misplaced priority in terms of government outlay.

Practical Implications: The implication presented in this paper is meant for the concerned authorities. The results indicate the need for the subnational governments in Nigeria to cut the overhead costs of governance by reducing the frivolous expenditures in order to curtail the incessant borrowing habit of these tiers of government locally and internationally.

Originality/value: Despite the fact that factors determining subnational fiscal behavior have been approached from diverse ideological and methodological perspectives, yet, the challenges linger on, the paper, therefore, employed sophisticated econometric technique to examine why the finances of the lower level of governments in Nigeria have not been managed optimally.
\end{abstract}

\section{INTRODUCTION}

Broadly defined, inequality and poverty have remained high and persistent in African economies despite the high growth experienced in the three decades before the very recent dismal performance in these economiesas a result of global resource price shocks (Ogunsola, 2019). Poor governance has been blamed as one key factor for the increasing inequality and poverty. This is especially at sub-central levels of governance. Fiscal performance at the lower levels of government has not been adjudged adequately and the sub-national governments have not contributed the much-required succor to lift the majority of Africans from poverty, thus creating concerns for development effort (Afonso\& Sebastian, 2019). 
An examination of the fiscal behavior of subnational governments would assist in identifying policy-relevant suggestions which may meet the challenges of development in Africa. There are several factors which deserve consideration in studying fiscal behavior. For instance, due to natural resource price shocks, some African economies experience recessions, unable to meet fiscal obligations leading to higher public debt levels in some (Goodfellow, 2018). Therefore, the behavior of public expenditure (recurrent and capital), debt (domestic and foreign) and total revenue before, during and after 2008-2009 financial/economic crisis and recent price shocks would be worth studying.

Government borrowing arises when its spending requirement (expenditure) is greater than its current receipts from regular sources, particularly, statutory allocation and internally generated revenue. (Abraham, 2016). Abraham (2016) further noted that public debt carries repayment terms of not only the amount borrowed but also interests and other debt servicing charges(2016). It should also be noted that the functioning of the subnational governments in the fiscal sense denotes majorly revenue and expenditure assignments. Tahir \& Perver (2017) observed that giving the sub-national governments the authority to raise loans from both the domestic and international sources did not yield the expected results of economic development. However, Heid \& Smith (2015) indicate that alternative sources are needed for economic growth at the subnational levels.

Many State governments are genuinely eager to grow their internally generated revenue base, they seem largely unable to harness available opportunities to do so (Olorungbemi, 2018). Many legitimate sources of revenue remain unexploited, while procedures for collecting, remitting and accounting for the ones exploited often fall short of expectations, giving room for avoidable leakages. Similarly, many States adopt revenue collection approaches that stifle instead of promoting business competitiveness. In some instances, exigencies and need seem to override rationality and care in the design of processes for the collection of internally generated revenue. Many lack the database for taxation, leading to reliance on unscientific procedures for tax collection and over-taxing of the few individuals and firms that are accessible to government institutions and representatives.

Over the years, it has been observed that many states are not enhancing their capacities to collect or expand their revenue bases. Every year the same figures are projected as total internally generated revenue in their budgets while corresponding personnel costs increases (Balogun, 2015). Hence, any reduction in the collection of statutory revenue from the federation account results in personal costs being unpaid. This makes such states not economically viable for existence (El-Rufia, 2012).

Thus, factors determining subnational fiscal behaviour have been approached from diverse ideological and methodological perspectives, yet, the challenges linger on, hence the need for this study.

\section{LITERATURE REVIEW}

Several studies such as Ter-Minassian (2017), Bahl \& Bird (2018) Olorungbemi (2018) and Bird and Tassonyi (2020) have addressed the determinants of sub-national fiscal behaviour and assessment of various sources of sub-national government revenue. Nonetheless, many of these studies are of empirical and theoretical outlook. Questions like what factors determine subnational government fiscal behaviour have been approached from diverse ideological and methodological perspectives. For instance, Ter-Minassian (2017) indicates 
that fiscal discipline and not political will is the determinant; Bahl \& Bird (2018) suggests that subnational governments will need much more real taxing power than they presently have access to; Olorungbemi (2018) observes that internally generated revenue facilitates is a factor to be reckoned with while Bird and Tassonyi (2020) revealed that the responsibilities of provincial governments are much more transfer-dependent. Thus the focus of this paper is on the fiscal stance of the lower level governments in Nigeria.

\section{Theoretical Issues}

The determinants of government expenditure have received considerable attention in Public Finance literature and one of the theories explaining this phenomenon is the Leviathan theory propounded by Thomas Hobbes (1651). The theory emphasizes government expenditure. This theory proposes that the aggregate government's intervention in the economy will be reduced as the taxes (revenues) and expenditures are reduced, ceteris paribus. This theory maintains that the more decentralized the central government, the lower the government spending in the economy because the decentralized unit will be responsible for revenue generation and expenditure disbursement. By this, the pressure on the central government reduces and it is transferred to the sub-national governments. Hence, there is a possibility for a more predicted fiscal behavior of government at the subnational levels.

Empirically, based on a series of econometric estimations for assistance allocation model parameters, Sinelnikov et al. (2019) test the degree to which the principle of allocation of financial assistance in the Russian federation created incentives for regional authorities to change the amount of public and private goods. They confirm that under certain situations, not only the grant type but also the specific allocation mechanism can introduce adverse fiscal incentives for subnational authorities such that subnational authorities' decisionmaking with respect to tax revenue and budgetary spending are altered by a change in the assistance allocation principle. Other findings show that by providing answers to the question of whether local government operates their finances against the boom-burst cycle, at the state level, stabilization is more a combination of economic stimulus, and that the pro-cyclicality of expenditures on capital infrastructure and their service provision is proportionate to the size of the state's economy (Clemens\& Miran, 2018).

Following multiplier estimates, Clemens \& Miran (2018) argued that balanced budget requirements are found to lead to substantial pro-cyclicality in state government spending, with the stringency of a state's rules driving the pace at which it must adjust to shocks and also that fiscal institutions can generate natural experiments in deficit-financed spending that are informative regarding fiscal stabilization policy. However, in examining the interaction between fiscal rules applying to European Union (EU) member states and fiscal decentralization, a trend which has been on the increase since the early ' 90 s in some European countries, Balassone et al. (2018) find that in practice there has been little recourse to formal rule as the strengthening of consensus-based institutions and procedures has been privileged. Also, Ter-Minassian (2017) indicates that fiscal rules cannot be a conduit to fiscal discipline if the political will is lacking, and are not the only solution to improving poorly designed systems of intergovernmental fiscal relations. But if fiscal authorities are driven by debt stabilization and sustainability motives, the existence of fiscal rules, and a lower degree of public spending, decentralization will positively contribute to higher responsiveness of primary surpluses to government indebtedness (Afonso \& Sebastian, 2019). 
A related strand of literature focuses on constraints facing local revenue mobilization, and the effectiveness of property tax policy in the light of international standards. Bird and Tassonyi (2020) revealed that Canadian municipalities are basically dependent on provincial governments, their responsibilities are also fairly well-defined, while they are much more transfer-dependent. In addition to their findings, subnational fiscal behavior in Canada is constrained by the lesson of history, instilling prudent fiscal behavior seemed to have performed fairly well by the different systems.

Furthermore, in urban settings in Africa, Fjeldstad \& Heggstad, (2019) find that the local revenues mobilization in most urban authorities in Africa is necessary, but not sufficient to develop and supply adequate service for the fast-growing urban population. The findings in most of the literature suggest that the failure of urban local governments to provide basic services to a growing population is mainly due to major hurdles to property ratings, such as poor property data systems, political interference, non-enforcement of the law, the low budget deficit in financing revaluation, insufficient staffing, and insufficient technical capacity of the few staff available (Kuusaana, 2019; Goodfellow, 2018).

On fiscal decentralization, Bahl \& Bird (2018) suggest that subnational governments will need much more real taxing power than they presently have access to, if fiscal decentralization is to yield sustainable net benefits in developing countries. Decentralization has been found to have an impact on selected local policies and also have important bearings on land use policy and property taxation (Ingram \& Hong, 2018; Kelekar, 2018). Much prior concern about fiscal decentralization reforms in Africa tends to emphasize the composition of local government 'own' revenues, administrative practices, and how the current system affects economic efficiency and accountability. Findings show that local government tax systems in many African countries have remained largely unchanged since independence, contrary to central government tax systems, and also the central government's control of the local revenue system remains strong, while the Francophone countries in West Africa is stronger than in Anglophone East Africa (Fjeldstad \& Heggstad, 2019).

In Ghana, Prichard \& Boogaard (2019) argued that informal practices sometimes enhance greater equity and responsiveness than formal rules, however, in other cases stand to reinforce existing inequalities. And on the property tax reform experience of the four largest city councils in Sierra Leone, Jibao \& Prichard (2019) identify three factors central to explaining the relative success and failure of reform. They include; international and central government support, political leadership, and a virtuous cycle of improved governance to strengthen local government taxation in low-income countries.

In the context of Mexican municipalities, Pöschl (2019) argues that the level of government's popularity and exertion of trustworthiness would determine the extent of tax collection and the degree of residents' willingness to pay. On a compliant level, regarding local municipalities in South Africa, one-third of municipalities do not comply with the requirements that a considerable amount of current expenditure is financed by means of own resources (Neik, 2019). In general, Aaberge \& Langorgen (2017) explained that by seeking the remedy to the inter-temporal utility maximization, small municipalities normally face higher per capita production costs than large municipalities, owing to scale economics in service production. 
Major findings on Nigeria revealed that the system of financial regulations and the inbuilt financial control mechanism are side-tracked by state and local government officials for selfish ends (Inyokwe, 2019). Considering these prevailing conditions and the nexus between internally generated revenue and the level of development, Olorungbemi (2018) observes that internally generated revenue facilitates rapid development in Nigeria, and as such local governments should strive towards improving internally generated revenue and instill transparency and accountability in their management structure. More specifically, on the challenges facing local internally generated revenue and the taxation system in the five South Eastern states of Nigeria.

\section{METHODOLOGY AND PROCEDURES}

\section{Model Specification}

Following Murshed et al. (2017), the empirical hypothesis of the paper is that States' expenditure is a function of states' fiscal capacity: which comprises both revenue and borrowing. Therefore, State's expenditure is a function of the revenue capacity (i.e. total revenue and borrowing) of a State which is expressed as a causal relationship among these variables (Asimiyu\& Kizito, 2019). The choice of these variables is appropriate as a State's expenditure mainly depends on that particular level of government's total revenue.

Therefore, the base model for the study takes the following form:

$$
Y=f(X)
$$

Where,

\section{$Y=$ Subnational Governments ${ }^{\prime}$ Expenditure and \\ $X=$ Fiscal capacity of Subnational Governments}

Also, the resources available to the States may be diminished; to this end debt servicing was incorporated as an explanatory variable as well.

The equation 1 above can be expressed in an estimable econometric equation as

$$
E X P_{t}=\beta_{o}++\beta_{1} T R E_{t}+\beta_{2} D M L_{t}+\beta_{3} F R L_{t}+\varepsilon_{t}
$$

The various cointegration and non-cointegration cases involving Expenditure (EXP), Total revenue (TRE) (comprising Federal allocations to the lower level governments and Internally Generated Revenue (IGR) of the subnational governments and debt [domestic (DML) and foreign (FRL)] are tested within the ARDL equation and is specified as:

$$
\begin{aligned}
E X P_{t}=\beta_{o}+ & \pi_{1} E X P_{t-1}+\pi_{2} T R E_{t-1}+\pi_{3} D M L_{t-1}+\pi_{4} F R L_{t-1}+\sum_{i=1}^{j} \beta_{1} \Delta E X P_{t-1} \\
& +\sum_{i=1}^{k} \beta_{2} T R E_{t-1}+\sum_{i=1}^{m} \beta_{3} D M L_{t-1} \sum_{i=1}^{n} \beta_{4} F R L_{t-1} \\
& +\varepsilon_{1 t}
\end{aligned}
$$

The null hypotheses for the tests are defined as follows:

(i) $F$-test on the lagged levels of all variables: $H_{0}: \pi_{1}=\pi_{2}=\pi_{3}=\pi_{4}=0$ against $H_{1}$ : any, $\pi_{1}, \pi_{2}, \pi_{3}, \pi_{4} \neq 0$

(ii) $t$-test on the lagged level of the dependent variable: $H_{0}: \pi_{1}=0$ against $H_{1}: \pi_{1} \neq 0$ 
(iii) $F$-test on lagged level of the independent variable: $H_{0}: \pi_{2}=\pi_{3}=\pi_{4}=0$ against $H_{1}$ : any, $\pi_{2}, \pi_{3}, \pi_{4} \neq 0$

Cointegration in the ARDL framework requires that the coefficients on the lagged levels of all variables in an unrestricted error correction equation be jointly significant.

The paper employed a technique of Augmented Autoregressive Distributed Lag (ARDL) introduced by Pesaran et al (2001). Though there is no much difference between the conventional ARDL and Augmented ARDL at the level of estimation, but at the level of testing, the Augmented ARDL takes the testing further. It involves an extra F-test on the lagged levels of the independent variables in the ARDL equation.

\section{RESULTS AND DISCUSSION}

\section{Unit Root Tests}

To ascertain the order of integration, the paper began by applying the Augmented DickeyFuller (ADF) and Phillips Perron (PP) unit root tests. The lag length determination for the ADF test is based on the Schwarz Information Criterion (SIC), while the PP test uses the Bartlett kernel for its spectral estimation and the Newey-West method for its bandwidth determination. The ADF and PP tests suggest that the variables are each integrated either at levels or of order one.

Table 1. Unit Root Tests Results

\begin{tabular}{|c|c|c|c|c|c|c|}
\hline \multicolumn{4}{|c|}{ Augmented Dickey-Fuller (ADF) Test } & \multicolumn{3}{|c|}{ Philips-Perron (PP) Test } \\
\hline Variables & Level & 1st Difference & Status & Level & 1st Difference & Status \\
\hline TRE & 0.1693 & $-7.4114 * * *$ & $\mathrm{I}(1)$ & 0.1663 & $-7.4114 * * *$ & $\mathrm{I}(1)$ \\
\hline EXP & -1.5767 & $-3.2145^{* *}$ & $\mathrm{I}(1)$ & 1.7531 & $-9.4207 * * *$ & $\mathrm{I}(1)$ \\
\hline DML & -1.6624 & $0.9414 * * *$ & $\mathrm{I}(1)$ & 0.7184 & $-7.4498 * * *$ & $\mathrm{I}(1)$ \\
\hline FRL & -0.4694 & $0.402636^{* * *} *$ & $\mathrm{I}(1)$ & -0.1877 & $-7.6002 * * *$ & $\mathrm{I}(1)$ \\
\hline $\begin{array}{l}\text { Critical } \\
\text { values }\end{array}$ & Level & 1st Difference & $\begin{array}{c}\text { Critical } \\
\text { values }\end{array}$ & Level & 1st Difference & \\
\hline $1 \%$ & -3.5461 & -3.5482 & $1 \%$ & -3.5461 & -3.5482 & \\
\hline $5 \%$ & -2.9117 & -2.9126 & $5 \%$ & -2.9117 & -2.9126 & \\
\hline $10 \%$ & -2.5936 & -2.5940 & $10 \%$ & -2.5936 & -2.5940 & \\
\hline
\end{tabular}

Source: Author's computation from the data extracted from CBN statistical bulletin and National Bureau of Statistics $(1961-2020)$.

The results of unit root tests are reported in Table 1 . The results show that all the variables are integrated at order one I(1). Since the results revealed that all the variables are stationary at first difference. However, at different levels of significance, it becomes econometrically reasonable to conduct the cointegration test.

\section{Augmented ARDL bounds test for cointegration}

The cointegration test under the bounds framework involves the comparison of the Fstatistics against the critical values, which are generated for specific sample sizes. The bounds testing procedure leaves open the possibility of an inconclusive test result if the test statistic falls between the lower and upper bounds. In this case, there are two possible courses of action. The first is to test the orders of integration of each explanatory variable. If they are all $I(0)$, then use the lower bound as the true critical value; if they are all $I(1)$, then the upper bound is appropriate. Thus, the results in Table 1 above show that all the variables are stationary at first difference i. e. I(1), then the upper bound is is used. 
Table 2. Augmented ARDL Bounds Test for Cointegration Results

\section{F- Statistics}

Number of independent variables $-k$

Critical values

\subsection{2}

4

\begin{tabular}{ccccc}
$\begin{array}{c}\text { Lower } \\
\text { bound }\end{array}$ Upper & Lower & $\begin{array}{c}\text { Upper } \\
\text { bound } \\
\text { bound }\end{array}$ & $\begin{array}{c}\text { Lower } \\
\text { bound }\end{array}$ & $\begin{array}{c}\text { Upper } \\
\text { bound }\end{array}$ \\
\hline $\begin{array}{c}\text { Asymptotic: } \\
\text { n=1000 }\end{array}$ & $\begin{array}{c}\text { Finite Sample: } \\
\mathbf{n}=\mathbf{6 0}\end{array}$ & $\begin{array}{c}\text { Finite Sample: } \\
\mathbf{n}=\mathbf{5 5}\end{array}$
\end{tabular}

$\begin{array}{ccccccc}10 \% & 2.2 & 3.09 & 2.323 & 3.273 & 2.345 & 3.28 \\ 5 \% & 2.56 & 3.49 & 2.743 & 3.792 & 2.763 & 3.813 \\ 2.5 \% & 2.88 & 3.87 & 3.71 & 4.965 & 3.738 & 4.947 \\ 1 \% & 3.29 & 4.37 & 2.323 & 3.273 & 2.345 & 3.28\end{array}$

Source: Author's computation from the data extracted from CBN statistical bulletin and National Bureau of Statistics (1961 - 2020)

The results of ARDL bounds test revealed that F-test is 7.692. The value of the estimated Fstatistic of the model has exceeded the upper bound at the $1 \%$ level of significance. It was apparent from the results that there exists a long-run relationship among the variables. This implies that the series are related and even if there are shocks in the short-run, which may affect the movement in the individual series, they would converge with time (in the long run). This is an indication that the variables are cointegrated and there is a presence of significant long-run relationships among the variables.

\section{Determinants of Fiscal Behaviour of Subnational Governments in Nigeria}

In an attempt to examine the factors determining subnational fiscal behavior between 1961 and 2020, a technique of Augmented Autoregressive Distributed Lags (ARDL) was used and the results are presented in Table 3 below.

Table 3. Augmented Autoregressive Distributed Lags (ARDL) results

\begin{tabular}{ccccc}
\hline & \multicolumn{4}{c}{ Dependent Variable: EXP } \\
& Method: Autoregressive Distributed Lags (ARDL) (4, 4, 4, 4, 4) & \\
\hline Variables & Coefficient & $\begin{array}{c}\text { Std. Error } \\
\text { Short Run Estimate }\end{array}$ & t-Statistics & Prob. \\
\hline C & 6.3305 & 2.2948 & 2.7587 & 0.0096 \\
EXP(-1)* & -1.1263 & 0.1566 & -7.1930 & 0.0000 \\
TRE(-1) & -1.4474 & 0.2662 & -5.4369 & 0.0000 \\
DML(-1) & -2.3217 & 2.4259 & -0.9571 & 0.3459 \\
FRL(-1) & -3.8626 & 1.4282 & -2.7045 & 0.0110 \\
D(EXP(-1)) & 0.8680 & 0.2109 & 4.1156 & 0.0003 \\
D(EXP(-2)) & 1.5188 & 0.2202 & 6.8978 & 0.0000 \\
D(EXP(-3)) & 0.6738 & 0.1925 & 3.5003 & 0.0014 \\
D(TRE) & 0.0630 & 0.1329 & 0.4743 & 0.6386 \\
D(TRE(-1)) & 0.3864 & 0.2122 & 1.8212 & 0.0782 \\
D(TRE(-2)) & 0.6020 & 0.2280 & 2.6400 & 0.0129 \\
D(TRE(-3)) & 1.1385 & 0.1665 & 6.8383 & 0.0000 \\
D(DML) & -1.7385 & 0.3260 & -5.3324 & 0.0000 \\
D(DML(-1)) & -2.9274 & 2.0892 & -1.4012 & 0.1711 \\
D(DML(-2)) & 0.1747 & 1.8111 & 0.0965 & 0.9238 \\
D(DML(-3)) & 3.5474 & 1.8325 & 1.9358 & 0.0621 \\
D(FRL) & 1.0263 & 0.3488 & 2.9424 & 0.0061 \\
D(FRL(-1)) & 6.9566 & 1.5353 & 4.5310 & 0.0001 \\
D(FRL(-2)) & 4.7968 & 1.6726 & 2.8678 & 0.0074 \\
D(FRL(-3)) & 2.1701 & 1.8149 & 1.1957 & 0.2409 \\
\hline
\end{tabular}




\begin{tabular}{ccccc}
\hline \multicolumn{4}{c}{ Long Run Estimate } \\
TRE & -1.2850 & 0.1895 & -6.7814 & 0.0000 \\
DML & -2.0613 & 2.3603 & -0.8733 & 0.3892 \\
FRL & -3.4293 & 1.4539 & -2.3587 & 0.0248 \\
C & 5.6204 & 2.2723 & 2.4734 & 0.0191 \\
\hline
\end{tabular}

Source: Author's computation from the data extracted from CBN statistical bulletin and National Bureau of Statistics (1961 - 2020)

The results of the short-run analysis in Table 4 indicate that the linear relationship between the statutory allocation of Subnational governments (TRE) and expenditure (EXP) is positive but not significant. This is an indication that the total revenue of the lower level of government in Nigeria has been grossly inadequate to finance their expenditure.

Also, loans sourced locally (DML) confer a significant negative relationship with the expenditure of subnational governments in Nigeria in the short run. This implies that these loans, instead of using them for capital projects, may be diverted to recurrent expenditure which has no rate of turnover. The results support the findings of Clemens \& Miran, (2018) which conclude that the pro-cyclicality of expenditures on capital infrastructure and their service provisions are proportionate to the size of the state's economy. Contrary to this result, loans sourced abroad (FRL) confer a significant positive relationship with the expenditure of subnational governments in Nigeria in the short run. This is an indication that these loans contribute significantly to the overall outlay of the lower levels of government in Nigeria in the short run.

The results of the long-run analysis appeared contrary to that of short-run estimations as to the linear relationship between total revenue of the subnational government (TRE) and expenditure (EXP) is negative. This shows that the revenue accruals to the lower level of Nigeria are no longer sustainable, hence, this is an indication that the subnational governments should look for additional viable internal revenue sources to complement revenue from the Federation Account to meet the yearnings of people at the grassroots. The results are in line with the view of El-Rufai (2012) that any reduction in the collection of statutory revenue from the federation account to the subnational governments results in personal costs being unpaid and this makes such levels of governments not economically viable for existence. The results are contrary to the findings of Neik, (2019) that a considerable amount of current expenditure is being financed by means of own resources.

Domestic loans (DML) and foreign loans (FRL) maintain a negative relationship with the expenditure (EXP) of subnational governments in Nigeria in the long run. The impact of the former is not significant while that of the latter appears significant at $5 \%$. The results suggest that loan accruals of the lower-level governments in Nigeria have not translated to the desired growth. This aligns with the findings of Tahir \& Perver (2017) which observed that the subnational government's ability to raise loans from both the domestic and international sources did not yield the expected results of economic development.

Table 4. Wald Tests: Augmented ARDL

\begin{tabular}{cccc}
\hline Test Statistics & Value & Prob. & Decision \\
\hline $\boldsymbol{F}_{\text {overall }}$ & 306.55 & 0.0000 & Co-integrated \\
$\boldsymbol{t}_{\boldsymbol{D V}}$ & -1.3117 & 0.0192 & Co-integrated \\
$\boldsymbol{F}_{\boldsymbol{I V}}$ & 28.958 & 0.0000 & Co-integrated \\
\hline
\end{tabular}

Source: Author's computation from the data extracted from CBN statistical bulletin and National Bureau of Statistics (1961 - 2020) 
The results from Table 4 show that $F$-test on the lagged levels of all variables (F $\left.\boldsymbol{F}_{\text {overall }}\right)$ is significant at $1 \%, t$-test on the lagged level of the dependent variable $\left(\boldsymbol{t}_{\boldsymbol{D V}}\right)$ is also significant at $5 \%$ while $F$-test on lagged level of the independent variables $\left(\boldsymbol{F}_{I V}\right)$ also appears significant at $1 \%$. The Null Hypothesis of no cointegration is rejected since the coefficients of the lagged levels of all variables in an unrestricted error correction equation are jointly significant. It can therefore be concluded that the variables are cointegrated and have a long-run relationship. The results imply that if the various sources of the fiscal capacity of the subnational governments in Nigeria are maximally harnessed, there is the likelihood of the revenue generated to finance the desired expenditure.

\section{CONCLUSION}

Total revenue of the lower-level governments in Nigeria has not made the desired impact on the finances of the lower levels of government. Also, it was found out that loans sourced locally and abroad have not been utilized optimally as there appeared a misplaced priority in terms of government outlay in this regard. It is, therefore, recommended that the subnational governments in Nigeria should cut the overhead costs of governance by reducing the frivolous expenditures to curtail the incessant borrowing habit of these tiers of government locally and internationally. The paper is only restricted to the fiscal behavior of subnational governments (Local and State governments alone) in Nigeria between 1981 and 2020. Thus, the fiscal behavior of the national government in Nigeria can equally be investigated.

\section{Conflict of Interest}

The authors declare no conflict of interest.

\section{Funding}

The authors did not receive funds towards conducting this research.

\section{REFERENCES}

Abraham, E. N. (2016). Is Nigeria's External Debt of Investment Grade? Debt Management Office Nigeria.

Aaberge, C. \& Langorgen, G. (2017) Taxing the Urban Unrecorded Economy in Sub-Sahara Africa. Paper Prepared for the "Hard to tax" conference, Atlanta.

Afonso H. \& Sebastian, S. (2019). Fiscal Behaviour in the European Union: Rules, Fiscal Decentralisation and Government Indebtedness. European Central Bank Working Paper Serie. 1054

Balogun, A. (2015). Developing Internally Generated Revenue in an Area of Diversification. Specialty Journal of Humanities and Cultural Science, 1(2), 1-22.

Balassone, S. Franco, B. and Zotteri, S. (2018). Local Government Discretion and Accountability: A Local Governance Framework. Social Development Working paper 13. Washington D.C.

Bahl, R. W. \& Bird, R. M. (2018). Subnational Taxes in Developing Countries: The Way Forwad. Public Budgeting and Finance. Institute for International Business Working Paper, 28(4), 1 - 25.

Bird, M. \& Tassonyi, A. (2020). Rethinking Tax Assignment: New directions for Subnational Taxes. Prepared for International Monetary Fund, Washinton D.C. 
CBN Statistical Bulletin (2020). Nigeria Statistical Fact Sheet on Economic and Social Development. Federal Office of Statistics, 10(6), 125 - 137.

Clemens, F. \& Miran, F. (2018). Africa in Local Government Finance: The Challenges of the $21^{\text {st }}$ Century. Second Global Report on Decentralisation and Local Democracy, Barcelona.

El-Rufai, N. (2012). Challenges Associated with Internally Generated Revenue (IGR) Collection. Paper Presentation. www.nigerianstat.gov.ng

Fjeldstad, O., Heggstad, H. and Kari, K. (2019). The Tax Systems in Mozambique, Tanzania and Zambia: Capacity and constraints. CMI Report, R2019: 3. Bergen: Chr. Michelsen Institute.

Goodfellow, T. (2018). Decentralisation, Local Taxation and Citizenship in Senegal. ICTD Working Paper. 38

Heid J. \& Smith M. (2015). Public Debt in Mexico: Policy Lessons for the Effective Oversight of State and Municipal Government Finances.

Ingram, G. K. and Hong, Y. (2018). Governance and Fiscal Federalism: The Challenges of Urbanisation. Lincoln Institute of Land Policy. Oxford University Press, New Delhi.

Inyokwe, Y. (2019). Fiscal Policy and Local Government Administration in Nigeria. An International Multidisciplinary Journal, 8(2),16-28. http://dx.doi.org/10.4314/afrrev.v8i2.8

Jibao, S. \& Prichard, W. (2019). Rebuilding Local Government Finances After Conflict: Lessons from a Property Tax Reform Programme in Post-Conflict Sierra Leone. The Journal of Development Studies, 52(1), $1759 \quad-\quad 1775$. https://doi.org/10.1080/00220388.2016.1153073

Kuusaana, E. D. (2019). Property Rating Potentials and Hurdles: What can be done to boost Property Rating in Ghana? Commonwealth Journal of Local Government. Development and Change, 5(6),67 - 75. http://dx.doi.org/10.5130/cjlg.v0i0.4495

Murshed, S. M., Badiuzzaman, M. and Pulok, M. H. (2017). Fiscal Capacity and Social Protection Expenditure in Developing Nations. United Nations University World Institute for Development Economics Research, WIDER Working Paper 2017/60, pp. $1-24$.

National Bureau of Statistics (NBS, 2020). Internally Generated Revenue at State level. www.nigerianstat.gov.ng

Neik, S. M. (2019). Fiscal Capacity and Social Protection Expenditure in Developing Nations. United Nations University World Institute for Development Economics Research, WIDER Working Paper 2017/60, 1 -24.

Olorungbemi, D. (2018). Local Governance in Nigeria: The Challenges of Democratic Decentralisation. Boulder, Lynne Rienner.

Pesaran, M. H., Shin Y. and Smith, R. J. (2001). Bounds Testing Approaches to the Analysis of Level Relationships. Journal of Applied Econometrics, 16, 289-326. http://dx.doi.org/10.1002/jae.616

Pöschl, C. (2019). Revenue Pressure on Mexican Municipalities: Does it lead to Greater Accountability? ICTD Working Paper No 29. 
Prichard, W. and Boogaard, V. (2019). Ground-level Realities of Market Taxation in Northern Ghana: Socially embedded Practices, Unequal Power and Implications for Taxation and Governance. African Studies Review, 5(7): 52 - 63.

Sinelnikov, D., Kadotchnikova, J. and Truuin, T. (2019). Analyzing Decentralisation Policies in Developing Countries: A Political Economy Framework. Development and Change - International Institute of Social Studies, 45 - 52.

Ter-Minassian, T. (2017). Intergovernmental Fiscal Relations in a Macroeconomic Perspective: An Overview. Fiscal Federalism in Theory and Practice, Washington D.C.: International Monetary Fund.

Tahir N. \& Pervez, T. (2017). Debt and Fiscal Responsibility in a Federal Structure: The case of Pakistan. Romanian Journal of Fiscal Policy (RJFP), 13 (2), 27 - 47. http://hdl.handle.net/10419/107944 